\title{
Social bonds: migration and comparative analysis of remitting behaviour between Pakistani and Indian diaspora
}

\section{Muhammad Zubair* and Dieter Bögenhold}

Sociology Department, Institute for Sociology, Alpen Adria University, Universitätsstr. 65-67, 9020 Klagenfurt, Austria Email: m1zubair@edu.at *Corresponding author

\begin{abstract}
Migration is a global phenomenon and has gained worldwide recognition for its socioeconomic impacts on host and home country. According to the literature, one of the most important emanations of migration are remittances. They facilitate poverty reduction, education improvement, entrepreneurial investments and even the economic evolution of the home state. Globally, India and Pakistan are in the top ten money receiving-countries. This paper provides an overview about migration, and the worldwide remittance flow of migrants from India and Pakistan to their home countries. We sought to make a nonlinear model by dividing remittance per person with the number of immigrants from India and Pakistan worldwide, also focusing on the ratio of male and female immigrants in the population. The results show that remittances change exponentially over the years. This increase is stronger in the case of India than Pakistan and, more interestingly, gender ratios have influenced remittances per year.
\end{abstract}

Keywords: migration; immigrant; immigration; remittance; gender; finance; diaspora; entrepreneurship; Pakistan; India.

Reference to this paper should be made as follows: Zubair, M. and Bögenhold, D. (2018) 'Social bonds: migration and comparative analysis of remitting behaviour between Pakistani and Indian diaspora', Int. J. Business and Globalisation, Vol. 21, No. 2, pp.180-192.

Biographical notes: Muhammad Zubair is a PhD student at the Department of Sociology, Faculty of Economics in Alpen-Adria-University Klagenfurt, Austria. He is working on Migration and Entrepreneurship. He did his Master's in Business Administration in Pakistan.

Dieter Bögenhold is a Professor of Sociology and the Head of the Department at Alpen-Adria University Klagenfurt (since 2011) before he had been engaged at various universities at different international places. He has published widely on globalisation, entrepreneurship, business and society and on the interface between economics, management and sociology. 


\section{Introduction}

The history of migration is started from the beginning of human life. People migrate from one region to another for better lifestyle and due to poverty. International migration classified mostly the movement, resettlement or relocation of an individual or a person from their native country to settle or live in another country. It can be either permanently or temporarily (Lee, 1966). According to Lee (1966), people move getting away wars and persecution, additionally in search of land, resources, opportunities and the fantasy of a better life.

Remittances are the transfers from foreign workers in home country, which are generally made from foreign workers to their family residing in home countries. Remittances from international immigrants to developing (home) countries consider being the largest source of financial inflow. In 2015, remittance inflow to developing countries estimated $\$ 431.6$ billion where the highest remittance inflow (72.2US\$) was recorded in India, while Pakistan is the eighth largest worker remittance (20.1US\$) receiving country [World Bank, (2016a), p.13].

The main purpose of this study is to examine the determinants of remittance flow in both top remittance receiving developing countries India and Pakistan per person and to check the gender share. This study tries to contribute to the research gap in terms of remittance per person share and gender role between India and Pakistan. In the past, studies are conducted to various aspects of migration and impact of remittance such as household, poverty reduction and economic growth, but they do not cover per person remittance share and the role of gender in it. Pradhan et al. (2008) find out remittance have a positive but small impact on growth. Aggarwal et al. (2006) found that remittances in developing countries have a significant effect on bank deposits. Zachariah and Rajan (2008) conducted a survey the end use of remittances by households in Kerala, a state in India, which shows that remittance have a very positive impact on household consumptions and economic growth at regional level. In case of Pakistan, many studies have been conducted to investigate the effect of remittances on the economy. Qayyum et al. (2008) examined the inflow of foreign remittances and its effects on the economic growth of Pakistan and poverty. Rahman (2009) investigated the stated relationship for four countries including Pakistan. Javid et al. (2012) focused on the inflow of remittances and its effect on economic growth and poverty in Pakistan. The main focused countries in this study are India and Pakistan.

According to United Nations, 'World population prospects' $(2015, \mathrm{p} .23)$ both India and Pakistan are among top ten populated countries. India is the 2nd most populous country of the world and Pakistan has the sixth highest population among developing country. Because of overpopulation, poverty, low education, health facilities, low wages and less availability of jobs in the market, people migrate to developed countries. Both countries have vast experience of migration, while immigrants from India and Pakistan are playing a vital role worldwide. They have very strong ethnic groups in the host society and rich family networks. However, they are mostly linked with the family residing in the home country and they are sending money back home to improve the family household situation. 
Remittances are playing a very vital role as a growing external source of capital for in the economy of the developing countries. According to the International Monetary Fund (IMF) statistics, India and Pakistan are two most remittance receiving developing countries worldwide, which shows that the remittance is not only playing a role to improve the poor condition, health and education of their families back home, but also in the GDP of their host countries. Finally, remittances provide evidence of diverse worldwide existing social networks (Bögenhold, 2013) which hold families together. Those family bonds give prove of transnational forces of social activities. The ties serve as a social capital at micro and macro levels (Coleman, 1988; Putnam et al., 1933; Ostrom, 2010).

In this paper, we make a nonlinear model to calculate the foreign remittance per person from worldwide to India and Pakistan and examine the role of gender using the same procedure. The numbers of immigrants from India are higher compared to Pakistan. Statistics show that immigrants from Pakistan were sending more money per year before 1990 however, after that, immigrants from India surpassed them. Both functions, from India and Pakistan, follow exponential distributions, where there is an exponential increase in money being sent back to home countries. We also correlate the variables and found that they are behaving in the similar way. In the final section, this study found some interesting results between male and female foreign remittance to Pakistan and India.

\section{Literature review}

The term immigrant is generally defined in the following way: "Migrant is a person who moves from one country to another country with the target or goal of taking up his residence there for an appropriate period of time" [Faist, (2000), p.18]. People have moved from pre-memorable times, pilgrims, paddlers, merchants and colonisers. From a worldwide perspective, currently numerous people are permanently on the move, being global migration a key component of an advanced open society [Massey et al., 1993; Kourtit and Nijkamp, (2011), p.167]. The word migration has many definitions because different researchers defined migration in different ways. Migration is broadly defined as a change of place or temporary residence or permanent (Lee 1966). International migration is mostly classified as the movement, resettlement or relocation of an individual or group of people from their native country to settle or live in another country (Bögenhold, 2014).

Migration is a very indulging and well-studied topic because of different socioeconomic concerns about changing demographics of countries, growing assistance of people, low wages for workers, need for skilled workers, reunification of families, growing population and support as well. The worldwide new trends have been one of increased flow of immigration (Dana, 1993). In the current perspective, it is observed that people who belong to weaker states or come from developing countries tend to move or migrate to stronger, more stable and developed countries for different reasons. Primarily this is due to economic reasons (labour, demand, promising opportunities, etc.) since the resources in their home country are too scarce to meet their needs. Inequality of income is a chronic problem of poor countries that leads to migration (Stark, 2006).

Waldinger (1989) supposed that people migrate temporarily as labourers or workers but sometimes it can also be permanent or sojourning immigration status in developed 
host societies. The Southeast Asian region has had a long history of conflict, war and internal divisiveness, as a result, there are a large number of people migrated to foreign countries for a better lifestyle. The people from the Southeast Asian are very diverse in culture, religion and linguistics. A few studies show that there are some diverse experiences for ethnic minority immigrants and these experiences are based on the host country where they live (Koning and Verver, 2013; Ma et al., 2012; Inal et al., 2012). Particularly, it consists of religions such as Hindu, Christianity, Buddhist and Islam [Pempel, (2005), p.1]. On the other hand, these groups are very strong in the family business. According to Hamilton et al. (2008), migrant groups are a very strong linkage to the culture, especially in which people grew up.

The past 40 years' studies show that immigrants often tend to create new ventures (Dana and Morris, 2007). International migration rapid increase in developed countries and immigrant's contribution in the host country economy is the main reason of studies, especially immigrant's contribution as an entrepreneur in the labour market. (Wong and Primecz, 2011; Head and Ries, 1998; Dana 1993). Immigration and entrepreneurship are so very much typical for the 21 st century (Dana and Morris, 2007). Dana (1997) study on 'the origin of self-employment' introduced the term describing entrepreneurs involved in bounded entrepreneurship.

The immigrants from India and Pakistan have migrated to the developed nations due to diverse socioeconomic reasons and they develop a global diaspora in their host countries. They show to become well settled and recognised ethnic groups in the whole world with tremendous development implications (Burki, 2011a). In the USA, Indian immigrants are well known as professional and working in highly skilled occupations. In 1990s, Indians immigrants found attraction in the USA because of the information technology boom in the American economy. Looking at immigrants from India, self-employment often proves to be positive and desirable for them (Dana, 1993). According to Pio and Dana (2014) in an empirical study of Indian entrepreneurs in Christchurch, New Zealand, found that there is a deeper understanding of self-employed people of Indian ethnicity than being in the formal sector. Findings also indicate that the Indians in this study showed a great significance to financial security for themselves and their families. Ethnic entrepreneurship is a process of recognising opportunities in the host country market, while undertaking innovative, insecure and dangerous activities by people not from the country of residence, which is an effort to ensure own prosperity and for the family (Ramadani et al., 2014). According to Ramadani et al. (2014), his study found that the women entrepreneurs are also an important resource within the business sector.

Nowadays, foreign remittance is playing a vital role in immigrants, native countries because remittance is an evidence of international migration, which can be seen everywhere or we can also say that it is a visible product. Remittance is the best factor to measure the migration experience. The primary impact of migration is the growth in income of recipient country residents through the remittances (McKenzie and Sasin, 2007). It is also noted that a growing amount of remittances due to better economic situation and employment opportunities in the developed countries boosted the migration and makes an easier choice for people to migrate. The main factors supporting migration in a global world is the difference in expected earnings adjusted for migration cost (Borjas, 1990; Stark and Taylor, 1991). 
Remittances are generally classified as a share of a migrant's earnings sent from the immigrant's host country to the home country or place of origin. Once people move to other countries, many of them send money back to families and friends in their countries of origin known as remittances. The term remittance is mostly related to transfers sent by migrant workers in host countries, but it is also important that migrants and refugees having no benefit from the legal status of migrant workers also send remittances to home countries (Nair, 2009). Remittances are not only playing a vital role in many labour exporting countries in the shape of foreign exchange but also is a key factor for migrants for the consumer and investment behaviour of household. Remittances have become an important source of external financing for the developing countries (Anzoategui et al., 2014). Therefore, literature distinguishes also between monetary and social remittances as agents of development [Mavroudi and Nagel, (2016), pp.104-109]. Mainly remittances are being used for investment purposes by rural households (Lucas and Stark, 1985; León-Ledesma and Piracha, 2004). According to Arif (2009), foreign remittances are the main source of income and poverty reduction for migrants, their households and their communities residing in home country in many parts of the developing world. Migrant remittances contribute significantly to development and living conditions in those countries receiving those funds and some special policies can enhance remittance transfers and investments, in encouraging circular migration (De Haas, 2005).

IMF as a credible and reliable source does keep annual records and data of official remittances sent home by migrant workers, but still the illegal and informal or unofficial foreign remittance exists, e.g., family and friends, etc. IMF records also show that the official workers' remittances increased per year. This inflow to developing countries is ten times more than the last decade. Remittances are a good source to get rid of poverty of the family, help immigrants left behind in the home country, and as well helps to boost the economies of the receiving countries. According to Brzozowski (2012) the remittances which initially could be categorised as unnecessary consumption in a sense of just giving away money, may be seen, after careful analytical consideration, as productive investments. Those families who are receiving remittances have a better living standard, while they are mostly investing the foreign remittance in education and health. (Adam and Cuecuecha, 2010, 2013). India is on the top while Pakistan is the seventh largest developing country in term of receiving remittances in 2015. A huge number of workers from South Asia (India and Pakistan) are employed abroad and they send a significant amount of remittances to their homeland, which makes considerable share of GDP of their countries.

Here in below mentioned table, we can see the numbers of Indian and Pakistani immigrants worldwide and remittance flow per year.

\section{Methods}

The descriptive statistics are presented in the following tables. Table 1 shows the overall number of immigrants from India and Pakistan per continent. In this paper, we used overall number of immigrants in the world to calculate remittance per person. Table 2 shows the change of remittance in last seven years, while Table 3 depicts the change of the number of migrants over the last 53 years specific to India and Pakistan. 
Table 1 Immigrants worldwide population from India and Pakistan

\begin{tabular}{lccccc}
\hline Country & Asia & Europe & USA & Africa & Oceania \\
\hline India & $14,089,175$ & $6,300,000$ & $5,326,882$ & $2,784,182$ & 730,070 \\
Pakistan & 328,489 & $2,134,234$ & $1,204,474$ & 123,081 & 64,000 \\
\hline
\end{tabular}

Source: Own calculation from Government of Pakistan (2015) and

Non-resident Indians online since 1997

(http://nriol.com/indiandiaspora/statistics-indians-abroad.asp)

Table 2 Remittance (US\$) flow to India and Pakistan

\begin{tabular}{lccccccc}
\hline Country & 2009 & 2010 & 2011 & 2012 & 2013 & 2014 & 2015 \\
\hline India & 49.20 & 53.48 & 62.50 & 68.82 & 69.97 & 70.39 & 68.91 \\
Pakistan & 8.72 & 9.69 & 12.26 & 14.01 & 14.63 & 17.07 & 19.26 \\
\hline
\end{tabular}

Source: Own calculation from World Bank (2016a)

Table 3 Worldwide immigrants from India and Pakistan from 1960-2013

\begin{tabular}{lccccccc}
\hline Country & 1960 & 1970 & 1980 & 1990 & 2000 & 2010 & 2013 \\
\hline India & $9,411,000$ & $9,182,000$ & $8,845,000$ & $7,493,000$ & $6,411,000$ & $5,436,000$ & $5,338,000$ \\
Pakistan & $6,350,000$ & $5,106,000$ & $5,013,000$ & $6,556,000$ & $4,243,000$ & $4,302,000$ & $4,081,000$ \\
\hline
\end{tabular}

Source: Own calculation from Migration Policy Institute (2016)

Figure 1 Remittance per person between India and Pakistan

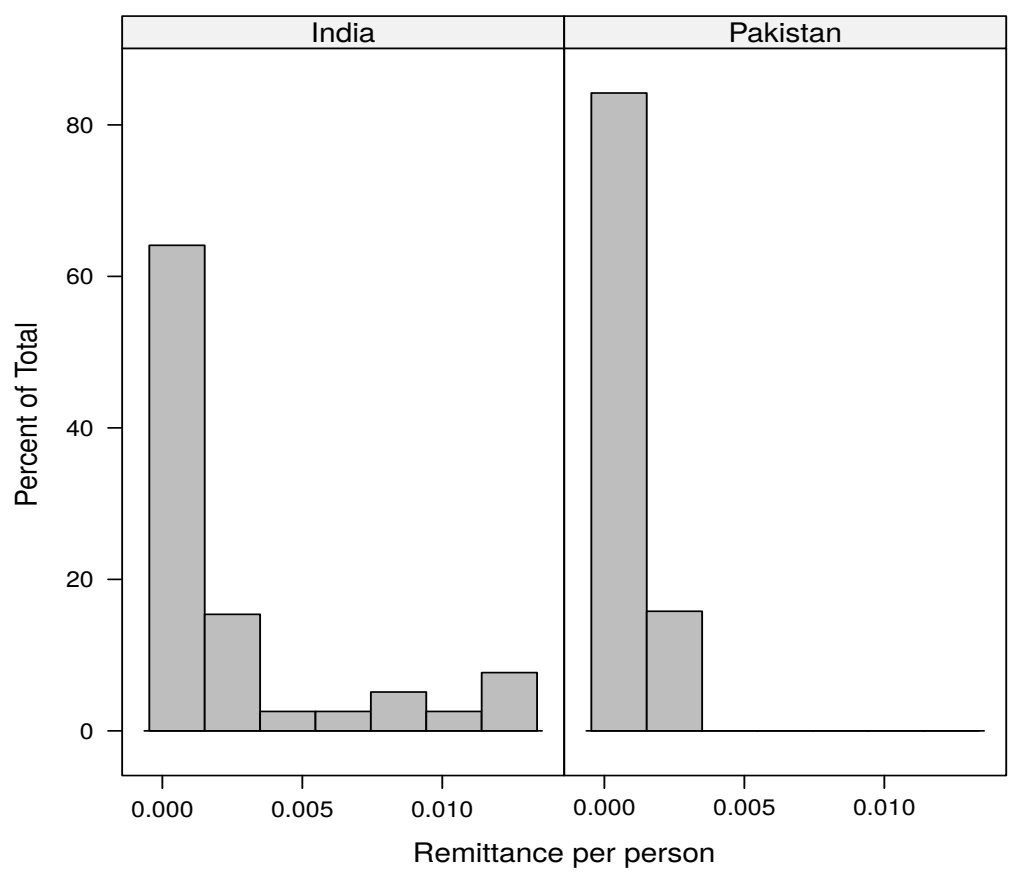


In this study, the data published by World Bank that gathers the remittance change in the last 46 years for different countries is used. This data spanned from 1975 to 2013 year separately for India and Pakistan, see Figure 1 for remittance in these two countries. Additionally, we collected the data for the overall number of immigrants in the world for these two countries, see Table 3. Data is also grouped as per the gender of the immigrants from each country and is used to investigate its influence on remittance rates. In the first step, we measure the correlation between the variables, which comprise of remittance, the number of immigrants, ratio of male and female immigrants and year. This helps in deducing the key variables involved in the model. In the second step, we derive a nonlinear model to explain the change of remittance over the years and gender population. In the following sections, we explain the nonlinear model in details followed by the results obtained from this model.

\section{Statistical analysis}

To investigate changes of remittance over the years, we used the newly introduced method of generalised additive modelling (GAMs). GAM is based on nonlinear regression that tries to capture the complete behaviour of the data over time (Wood, 2006). In case of commonly used linear regression, one needs to assume that the effect of remittance forms a linear trend over time. The usual approach is to investigate whether the independent variable (years in this case) changes the behaviour of remittance in linear fashion. That is, to see whether increase in one year brings a linear increase or decrease in the remittance. On the contrary, with GAM model, we optimise the nonlinear function that tries to explain the behaviour of remittance over time. The results of this model are usually presented over a time scale where one can see the change in the dependent variable over its independent counterpart.

In this study, we derive nonlinear curves of remittance over years, separately for India and Pakistan. Additionally, we also investigate how the ratio of men and women influence the remittance over time. The dependent variable in the model is remittance per person. It is calculated as remittance per year divided by the worldwide number of immigrants per country, for that year. The independent variables in the model are times in years and the ratio of male and female immigrants. Time spans from 1975 to 2013, granularity in years, whereas, the ratio is calculated as the number of worldwide female immigrants divided by number of worldwide male immigrants, per country. The aim of this model is not to make a prediction, but to investigate the differences in remitting behaviour specific to India and Pakistan.

The through statistical analysis of the data reveals the following GSM model:

$$
\text { Remittance }=\beta_{0}+f(\text { year, by }=\text { Country })+\text { Gender Ratio }
$$

Equation (1) illustrates the applied model in the study, where remittance is the dependent variable, $\beta_{0}$ is the intercept of the model, $f$ is the nonlinear function over the years and by argument specifies that this function is applied in each country (India and Pakistan), gender ratio is the ratio of female and male immigrant population that influences the amount of remittance. 


\section{Results}

Data analysis and model building are performed using $\mathrm{R}$, which is a powerful tool for statistical computing and graphical representation ( $\mathrm{R}$ core team, 2016). In the first step, we present the calculated correlation (denoted by $r$ ) between the main variables in Table 4. Results show that we have multiple variables having significant correlation.

Table 4 The correlation matrix imputing the significance of key variables

\begin{tabular}{lccccc}
\hline & \#Year & \#Remittance & \#Population & \#Migrants & Ratio \\
\hline \#Year & & $0.6182370 * * *$ & $0.2675369 * *$ & $-0.4908584 * * *$ & 0.01649845 \\
\#Remittance & $0.61823704 * * *$ & & $0.6296955^{* * *}$ & -0.1596184 & $0.54944021 * * *$ \\
\#Population & $0.26753692 * *$ & $0.6296955 * * *$ & & $0.4903572 * * *$ & $0.89513988 * * *$ \\
\#Migrant & $-0.49085845 * * *$ & -0.1596184 & $0.4903572 * * *$ & & $0.42337022 * * *$ \\
Ratio & 0.01649845 & $0.5494402 * * *$ & $0.8951399 * * *$ & $0.4233702 * * *$ & \\
\hline
\end{tabular}

Notes: $\mathrm{p}<.0001^{* * *} ; \mathrm{p}<0.01^{* *} ; \mathrm{p}>.05 \mathrm{~ns}$.

Figure 2 Comparison of remittance per person over the years between India and Pakistan

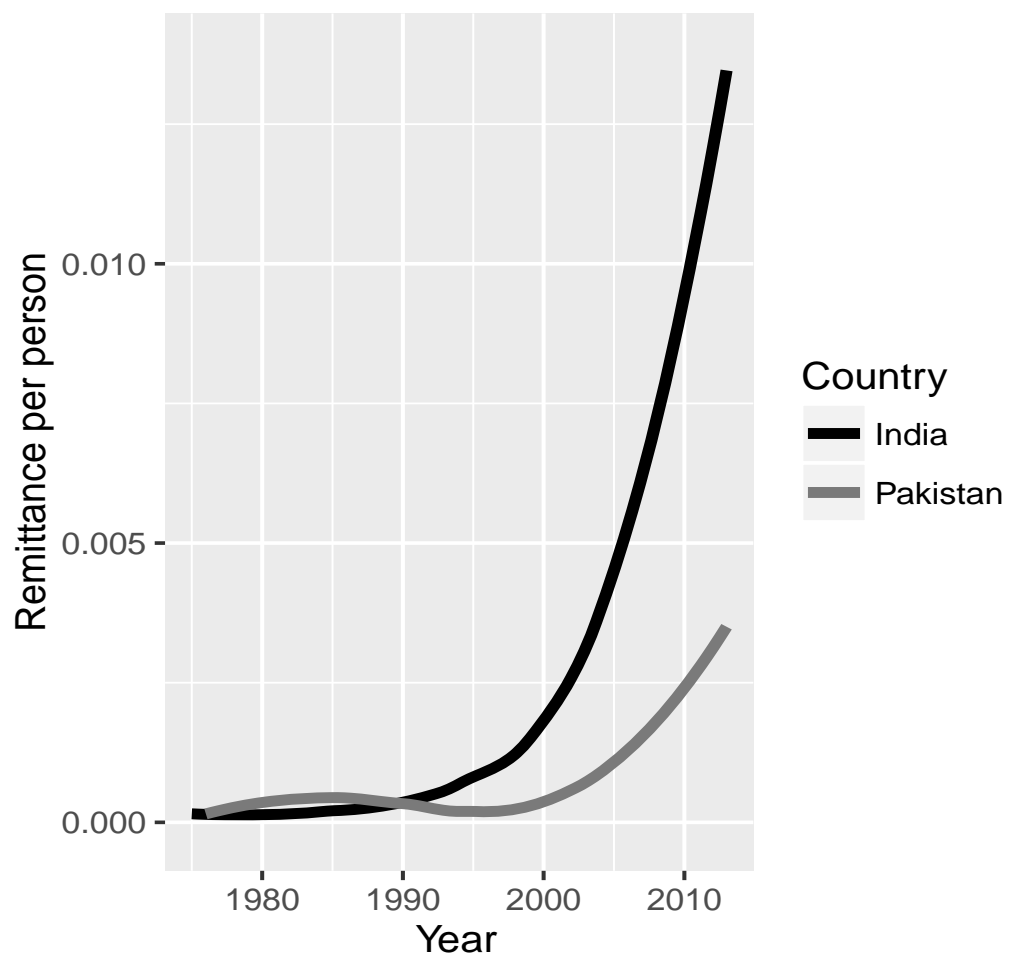

It is observed that the remittance correlates positively with time $(r=0.61, p<.001)$ showing that remittance tends to increase over time. The size of the population of the country also has a similar positive correlation with remittance $(r=0.62, p<.001)$, indicating that more populated the country is, more remittance is being accumulated. 
Finally, remittance and the ratio of the number of men and women in the immigrant population are also positively correlated $(r=0.54, p<.001)$, though not as strong as in earlier cases, showing that populations with equal number of women and men acquire more remittance. Results also show that immigrant populations negatively correlate with the year $(r=-.49, a=<.001)$, stating that there is a decline in the number of immigrants from these countries in the world over the years.

In the second step, we applied the model illustrated in equation (1) using mgev package in R (Wood, 2006, 2011). The variable used in the model explained approximately $85 \%$ of the data variance (measured by the $R^{2}$ - coefficient of determination). Figure 2 shows the effect of remittance over the years in India and Pakistan. Results show that the Pakistan was sending more money back in the early 1970s and 1980s. Starting from 1990s, there is a slight decline of remittance in the case of Pakistan, while India had a constant increase of remittance during the 1970s and 1980 s. For both countries, the remittance started increasing exponentially, where this increase of remittance came sooner for India than for Pakistan. That is, in the beginning of the 90s immigrants from India started sending more money back home, while this increase started around 2001 in the case of Pakistan. The figure shows, that remittance in the case of India has a larger increase than Pakistan, however, both countries have similar trend over time.

Figure 3 Remittance per person per gender ration from India and Pakistan together

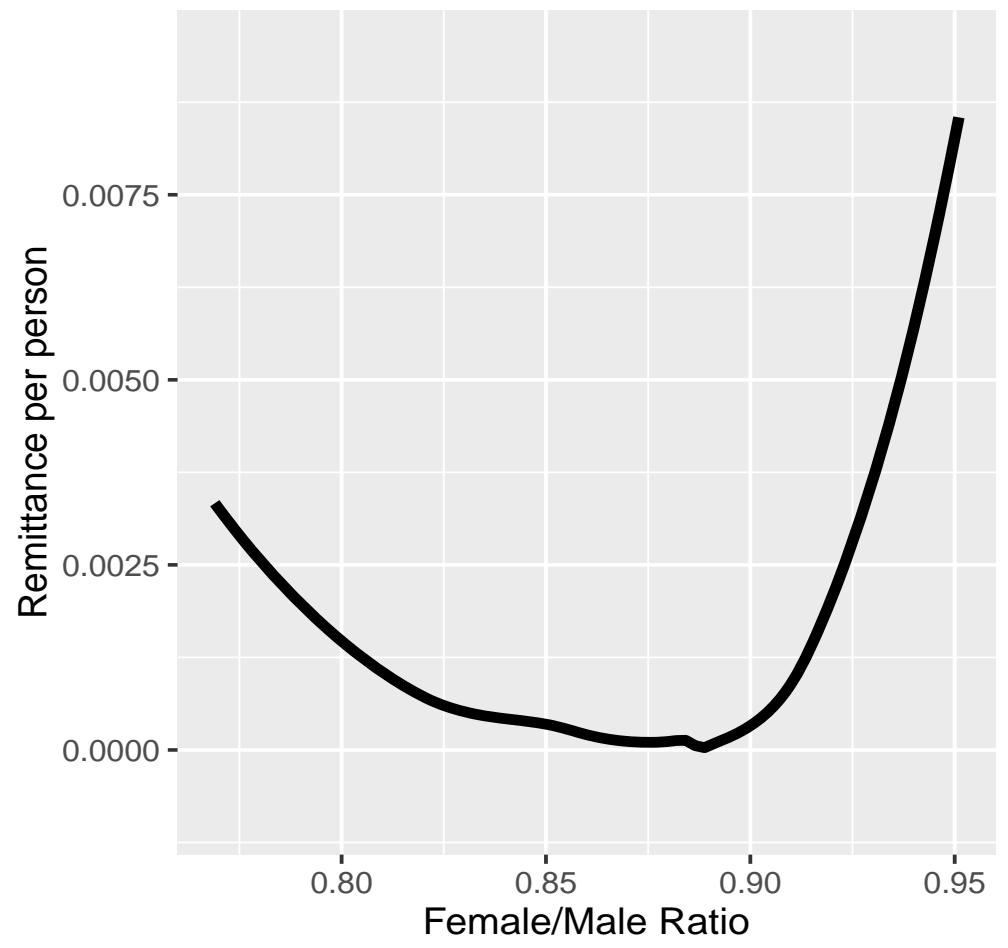

Figure 3 plots the effect of gender ratio on remittance. Lower values indicate more men compared with women in the population, while values closer to one indicate equal amount of men and women in the population. Results show that remittance function 
follows slightly U-shaped trend. The populations with predominantly male immigrant populations, in both countries, tend to send relatively more money back to their home countries; however, we can see by the shaded areas in the graph that the function here has more uncertainty. In other words, the first part of the function observes more variability in remittance. More interestingly, results show that the populations that are almost equal in the amount of men and women send the largest amount of money back home. This is indicated by the ratio that is close to one, meaning equal number of women and men, and at this part of the graph, we can see an increase of remittance being sent to the home country. Compared with the first part of the function, this part is less variable and better estimated.

\section{Discussion and conclusions}

International migration becomes a global phenomenon that is increasing rapidly with its complexity and impacts. People are moving from one place to another for better socioeconomic opportunities. Migration is as old as mankind. Mostly migration describes as people are moving from one place to another, it can be internal or external, temporary or permanent. Recently, people are also moving because of war, and persecution. It is clear that migration is good for the immigrants and thousands of researchers found that immigrants are playing a very vital role in the host economies. India and Pakistan are two developing countries of South-East Asia. Both countries have a very vast experience of migration. Immigrants from India and Pakistan are found in all continents, they are all types of immigrants, highly qualified people, skilled workers and refugees. They are also playing an important role as entrepreneurs. India is also one of the top students sending country worldwide.

People from India and Pakistan are moving from home countries because of low wages, poverty and political issues. They are well established having global diasporas. The immigrants from Pakistan and India are linked with families residing in home countries and frequently send a considerable amount of money back to their families. This helps to improve financial positions, education improvement and health facilities of concerned families. According to the statistics, India and Pakistan are two among the top ten countries receiving highest foreign remittance. This remittance is not only playing a role for households, but in the GDP of the both countries as well. In this study, we examined the remittance flow to both India and Pakistan. Before 1990, Pakistani immigrants sent more money to home country compared to India, but later the number of Pakistani immigrants went down. The reasons for that are not yet studied, but a rough guess would include reasons such as terrorism and international migration policies as well. On contrary to Pakistan, after 1990, Indian immigrants sent more money and are still on top. In this study, according to available data, we find some interesting results that the male and female immigrants from both countries in shape of equal numbers are sending more money, compared to more male migrants. In future studies that reason behind that will be thoroughly investigated and future research could be, comparing remittance consumption behaviour in home country of both Pakistani and Indian Diaspora.

Remittance is one of the income sources of earning foreign money in India and Pakistan and truly influences the income of the households as well as the GDP of the both 
countries. Pakistan and India are among the two-developing top ten remittance receiving Asian countries. This study analyses the remittance per person share and compares it between India and Pakistan. Overall findings suggest that remittance changes exponentially over the years. It means that remittance rapidly increasing in a last few years. This increase is higher and stronger in the case of India than Pakistan. More interestingly, gender ratio influenced remittance per year, showing that equal size of male and female contributed with more remittance than immigrant with more male population did.

\section{References}

Adams, R.H. and Cuecuecha, A. (2010) 'Remittances, household expenditure and investment in Guatemala', World Development, Vol. 38, No. 11, pp.1626-1641.

Adams, R.H. and Cuecuecha, A. (2013) 'The impact of remittances on investment and poverty in Ghana', World Development, Vol. 50, pp.24-40.

Aggarwal, R., Demirgüç-Kunt, A. and Martinez Peria, M.S. (2006) Do Workers' Remittances Promote Financial Development?, World Bank Policy Research Working Paper No. 3957, SSRN: http://ssrn.com/abstract=923264.

Anzoategui, D., Demirgüç-Kunt, A. and Pería, M.S.M. (2014) Remittances and Financial Inclusion: Evidence from El Salvador, World bank Paper series: wps 5839.

Arif, G.M. (2009) Economic and Social Impacts of Remittances on Households: The Case of Pakistani Migrants Working in Saudi Arabia, Pakistan Institute of Development Economics, Islamabad.

Bögenhold, D. (2013) 'Social network analysis and the sociology of economics: filling a blind spot with the idea of social embeddedness', The American Journal of Economics and Sociology, Vol. 72, No. 2, pp.293-318.

Bögenhold, D. (2014) Cultural Sociology of Mental Illness, edited by A. Migration, J. Scull and G. Golson, Vol. 1, pp.535-537, CQ Press and /Sage, New York and London.

Borjas, G.J. (1990) Friends or Strangers: The Impact of Immigrants on the US Economy, Basic Books, New York.

Brzozowski, J. (2012) 'International migration and economic development', Estudos Avançados, Vol. 26, No. 75, pp.137-156.

Burki, S.J. (2011a) South Asia in the New World Order: The Role of Regional Cooperation, Routledge, Abingdon.

Coleman, J. (1988) 'Social capital in the creation of human capital', The American Journal of Sociology, Vol. 94, pp.95-120.

Dana, L.P. (1993) 'towards a synthesis: a model of immigrant and ethnic entrepreneurship: case studies of business creation among immigrants in Montreal', Journal of Small Business and Entrepreneurship, Vol. 10, No. 4, pp.16-31.

Dana, L.P. (1997) 'The origins of self-employment', Canadian Journal of Administrative Sciences, Vol. 14, No. 1, pp.99-104.

Dana, L.P. and Morris, M. (2007) 'Towards a synthesis: a model of immigrant and ethnic entrepreneurship', in Dana, L.P. (Ed.): Handbook of Research on Ethnic Minority Entrepreneurship, p.803, Edward Elgar Publishing, Cheltenham.

De Haas, H. (2005) 'International migration, remittances and development: myths and facts', Third World Quarterly, Vol. 26, No. 8, pp.1269-1284.

Faist, T. (2000) The Volume and Dynamics of International Migration and Transnational Social Spaces, Oxford University Press, Oxford. 
Government of Pakistan (2015) Ministry of Labour, Manpower and Overseas Pakistanis: Year book 2013-2014, p.27[online] http://www.ophrd.gov.pk/ and http://www.nriol.com/indiandiaspora/ statistics-indians-abroad.asp.

Hamilton, R., Dana, L.P. and Benfell, C. (2008) 'Changing cultures: an international study of migrant entrepreneurs', Journal of Enterprising Culture, Vol. 16, No. 1, pp.89-105.

Head, K. and Ries, J. (1998) 'Immigration and trade creation: econometric evidence from Canada', Canadian Journal of Economics, Vol. 31, No. 1, pp.47-62.

Inal, G., Al Ariss, A. and Forson, C. (2012) 'Self-employment as a career strategy for ethnic minorities: the case of Turkish-Cypriots in Britain', Journal of Management Development, Vol. 32, No. 2, pp.166-181.

Javid, M., Arif, U. and Qayyum, A. (2012) 'Impact of remittances on economic growth and poverty', Academic Research International, Vol. 2, No. 1, pp.433-447.

Koning, J. and Verver, M. (2013) 'Historicizing the 'ethnic' in ethnic entrepreneurship: the case of the ethnic Chinese in Bangkok', Entrepreneurship and Regional Development, Vol. 25, Nos. 5-6, pp.325-348.

Kourtit, K. and Nijkamp, P. (2011) 'Strategic choice analysis by expert panels for migration impact assessment', International Journal of Business and Globalisation, Vol. 7, No. 2, pp.166-194.

Lee, E.S. (1966) 'A theory of migration', Demography, Vol. 3, No. 1, pp.47-57.

León-Ledesma, M. and Piracha, M. (2004) 'International migration and the role of remittances in Eastern Europe', International Migration, Vol. 42, No. 4, pp.65-83.

Lucas, R.E. and Stark, O. (1985) 'Motivations to remit: evidence from Botswana', The Journal of Political Economy, Vol. 93, No. 5, pp.901-918.

Ma, Z., Zhao, S., Wang, T. and Lee, Y. (2012) 'An overview of contemporary ethnic entrepreneurship studies: themes and relationships', International Journal of Entrepreneurial Behaviour and Research, Vol. 19, No. 1, pp.32-52.

Massey, D.S., Arango, J., Hugo, G., Kouaouci, A., Pellegrino, A. and Taylor, J.E. (1993) 'Theories of international migration: a review and appraisal', Population and Development Review, Vol. 19, No. 3, pp.431-466.

Mavroudi, E. and Nagel, C. (2016) Global Migration: Patterns, Processes, and Politics, Routledge, London and New York.

McKenzie, D. and Sasin, M.J. (2007) Migration, Remittances, Poverty, and Human Capital: Conceptual and Empirical Challenges, Policy Research Working Paper 4272, The World Bank Washington, DC.

Migration Policy Institute (2016) International Migrants by Country of Destination, 1960-2015 [online] http://www.migrationpolicy.org/programs/data-hub/charts/international-migrantscountry-destination-1960-2015?width=1000\&height=850\&iframe=true (accessed 18.05.2017).

Nair, R.P. (2009) The Impacts of Gender and Remittance on Household's Expenditure Pattern in Nepal, Unpublished Graduate Thesis, Graduate school of arts and science, Washington, DC.

Non-resident Indians online since 1997 [online] http://www.nriol.com/indiandiaspora/statisticsindians-abroad.asp (accessed 18.05.2017).

Ostrom, E. (2010) Foundations of Social Capital, Edward Elgar, Cheltenham.

Pempel, T.J. (2005) Remapping East Asia: The Construction of a Region, pp.1-10, Cornell University Press Ithaca and London.

Pio, E. and Dana, L.P. (2014) 'An empirical study of Indian entrepreneurs in Christchurch, New Zealand', Int. J. Entrepreneurship and Small Business, Vol. 22, No. 1, pp.17-35.

Pradhan, G., Upadhyay, M. and Upadhyaya, K. (2008) 'Remittances and economic growth in developing countries', The European Journal of Development Research, September, Vol. 20, No. 3, pp.497-506.

Putnam, R.D., Leonardi, R. and Nanetti, R.Y. (1993) Making Democracy Work: Civic Traditions in Modern Italy, Princeton University Press, Princeton. 
Qayyum, A., Javid, M. and Arif, U. (2008) Impact of Remittances on Economic Growth and Poverty: Evidence from Pakistan, MPRA papers.

Rahman, M. (2009) 'Contributions of exports, FDI, and expatriates' remittances to real GDP of Bangladesh, India, Pakistan, and Sri Lanka', South Western Economic Review, Vol. 36, No. 1, pp.141-154.

Ramadani, V., Rexhepi, G., Gërguri-Rashiti, S., Ibraimi, S. and Dana, L.P. (2014) 'Ethnic entrepreneurship in Macedonia: the case of Albanian entrepreneurs', International Journal of Entrepreneurship and Small Business, Vol. 23, No. 3, pp.313-335.

Stark, O. (2006) 'Inequality and migration: a behavioural link', Economics Letters, Vol. 91, No. 1, pp.146-152.

Stark, O. and Taylor, J.E. (1991) 'Migration incentives, migration types: the role of relative deprivation', The Economic Journal, Vol. 101, No. 408, pp.1163-1178.

United Nations (2016) 'Department of economics and social affairs: population division', World Population Prospects 2015 revision [online] http://www.un.org/en/development/desa/ population/events/other/10/index.shtml (accessed 18.05.2017).

Waldinger, R. (1989) 'Immigration and urban change', Annual Review of Sociology, Vol. 15, pp.211-232.

Wong, L. and Primecz, H. (2011) 'Chinese migrant entrepreneurs in Budapest: changing entrepreneurial effects and forms', Journal of Asia Business Studies, Vol. 5, No 1, pp.61-76.

Wood, S. (2006) Generalized Additive Models: an Introduction with R. CRC Press, Taylor and Francis group, USA.

Wood, S.N. (2011) 'Fast stable restricted maximum likelihood and marginal likelihood estimation of semiparametric generalized linear models', Journal of the Royal Statistical Society: Series B (Statistical Methodology), Vol. 73, No. 1, pp.3-36.

World Bank (2016a) Migration and remittance data: Annual Remittances Data (updated as of October 2016) [online] https://www.worldbank.org/en/topic/ migrationremittancesdiasporaissues/brief/migration-remittances-data (accessed 18.05.2017).

World Bank (2016b) Migration and Factbook 2016 [online] http://econ.worldbank.org/WBSITE/ EXTERNAL/EXTDEC/EXTDECPROSPECTS/0,,contentMDK:21352016 pagePK:6416540 1 piPK:64165026 theSitePK:476883,00.html (accessed 18.05.2017).

Zachariah, K.C. and Rajan, S.I. (2008) Migration and Development: The Kerala Experience, Daanish Publishers, New Delhi. 